\title{
Pushed to the edge. Inclusion and behaviour support in schools
}

\section{Eszter Neumann}

To cite this article: Eszter Neumann (2018) Pushed to the edge. Inclusion and behaviour support in schools, Journal of Education Policy, 33:3, 439-440, DOI: 10.1080/02680939.2017.1413767

To link to this article: https://doi.org/10.1080/02680939.2017.1413767

册 Published online: 10 Dec 2017.

Submit your article to this journal ¿

Џ Article views: 81

Q View related articles $\square$

View Crossmark data ¿ 
BOOK REVIEWS

\section{Pushed to the edge. Inclusion and behaviour support in schools, by Val Gillies, Bristol, Policy Press, 2016, 224 pp., Ł24.99 (paperback)/Ł70.00 (hardback), ISBN 9781447317470}

Val Gillies' book, Pushed to the Edge provides insight into the operation of behavior support units, a dominant form of the marginalization and exclusion of disadvantaged youth in contemporary English secondary education. While education policies focus on reducing rates of truancy, absences and young people not in either education, employment or training, there has been a proliferation of internal behavior support units for longer term referrals that are maintained by mainstream schools. Val Gillies unravels how, in the context of neoliberal pressure on schools, behavior support units developed as new forms of separating and phasing out disadvantaged youth from mainstream education. The book concentrates on how professional discourses conceptualize persistent disruptive behavior and how behavior support units govern the educational futures of students who are directed there.

While the analysis is conducted with scientific rigor and intellectual clarity, Gillies' style of writing is engaging and enjoyable, thus it should be warmly recommended to teachers and the wider public. The book is based on an in-depth ethnographic study of internal exclusion units in three London secondary schools. Research methods involved interviewing teachers, students and parents, as well as creative workshops held in the behavior units with the students. The workshops, where researchers acted as participant observers, involved drama, role play activities and other creative, art-based techniques. Gillies recounts the trials and tribulations of the ethnographic research process, such as the challenges of gaining access and the eventuality and spontaneity of the workshops, with remarkable vividness and honesty. She explains how these circumstances shaped and helped to focus the research process, and how they proved to be valuable data on the hidden curricula of the schools studied. However, more detail on the methodology of the workshops and the ways in which the action method exercises were analyzed could have made the presented empirical evidence even more persuading.

The findings compellingly support the core argument that therapeutic and psychological approaches promoted and prioritized by inclusion policies tend to personalize and psychologize troublesome behavior, and at the same time mask the persistent link between social deprivation and referrals to behaviour units. The empirical chapters are arranged thematically: from different aspects they explore how the discoursive order of therapeutic education constructs inclusion and justifies separation in the daily practices of the internal exclusion units. Analyzing student narratives, Gillies highlights the various experiences of disadvantage, such as migration, street violence and social deprivation, which are homogenized by the professional gaze that perceives them as psychological traumas and seeks treatment accordingly. The subsequent chapter focuses on how gender stereotypes guide teachers' interpretations of behaviour incidents in the schools studied. Gillies found that behavior incidents involving boys were habitually associated to anger management issues, hence they were approached as symptoms of personal pathology and dysfunction. At the same time, the trajectories of the girls who entered to the units were typically explained by developmental deficits, immaturity or 'neediness'.

Subsequent chapters continue to explore experiences that the therapeutic discourse fails to recognize, such as how race and behavior is narrated in the context of the celebratory approach of multiculturalism. Following up the author's long-standing interest on the deficit discourses about working class parenting, another chapter presents findings from interviews conducted with the 
parents of the students attending behavior units. This chapter focuses on parent-school relations, parents' views on education, and their experience of being accused of inadequate parenting.

The last empirical chapter elicits on how experiences of marginalization frame and inform young people's understanding of their futures. Reaching back to Paul Willis'seminal ethnography, Gillies asks how the prospects of students deemed 'troublesome' have transformed in the wake of desindustrialization and the neoliberalization of the labour market. Gillies suggests that in contrast to Willis' 'lads', students in the behaviour units are profoundly disturbed by their future prospects. They are distressed about losing out in education as they are fully aware of the importance of qualifications and that the roads returning to formal education are very limited for them.

Pushed to the Edge reveals how the complex systems of internal exclusions cut short educational trajectories and deprive marginalized youth from imagining their futures in education. Based on these findings, the book argues for an inclusion agenda which can encompass both psychological and sociological aspects, and therefore better support and equip teachers in meaningfully engaging with the complex effects of social deprivation on learning, educational performance, and being together in the school.

Eszter Neumann HAS Centre for Social Sciences Institute for Minority Studies Q Neumann.eszter@tk.mta.hu

\section{The toxic university: zombie leadership, academic rock stars, and neoliberal ideology, by John Smyth, London, Palgrave Critical University Studies, Palgrave Macmillan, 2017, 235 pp., GBP66.99 (hardback), ISBN 978-1-137-54976-1}

Authored by the Series Editor, this is the first volume in the Palgrave Critical University Studies Series, the explicit aim of which is to provide a 'forum for the intensive and extensive discussion of the consequences of ill-conceived and inappropriate university reforms. The premise of the series is that in the processes of higher education structural adjustment, the views of key groups have been silenced or marginalized, while the reforms have variously harmed, distorted, and perverted (Palgrave's words) the traditional language, practices and relations of western, social democratic university life. The Series Editor's Preface explains that its distinguishing feature will be its 'criticalist agenda', sharply focused on the discussion of academic work, academic freedom and marketization of the universities (vi). Smyth, now Professor of Education and Social Justice at the (post-1992) University of Huddersfield, England, calls for critical university studies that: provide 'existential accounts' of contemporary student life, insider studies of institutional politics in the neoliberal university; reveal the covert influence of transnational policy discourses and elite networks on the entrepreneurial university; document the now hegemonic governance and management practices that enable these; and explore the unique social geographies and spatialities of contemporary university life. Smyth ends his Preface with the hope that such contributions will advance 'the reclamation and restitution of universities as crucial intellectual democratic institutions' (vii).

In chapter one, Smyth acknowledges that his coining and borrowing of metaphors for the book's title and each of the contributing chapters are intentionally 'provocative'. Throughout the book, he shuttles between raw, very colourful polemic and a forensic, reflexive account of 